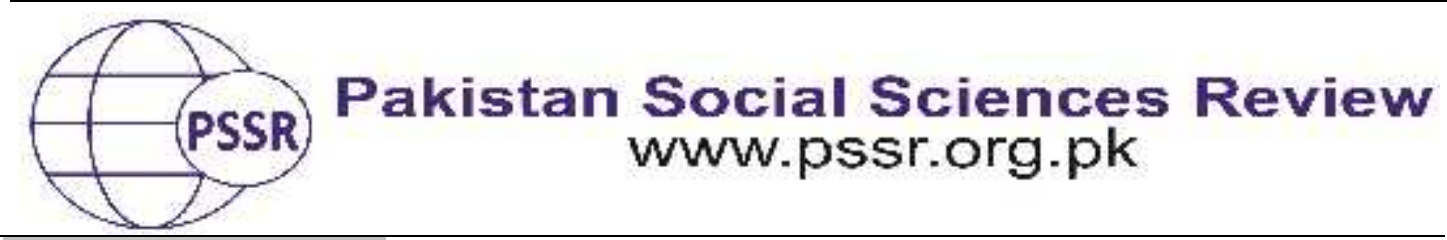

RESEARCH PAPER

\title{
Correlation Analysis of the University Teachers' Computer Self- Efficacy in Teaching and Research in Punjab (Pakistan)
}

\author{
Muhammad Rashid ${ }^{* 1}$ Dr. Ahmad Farooq Shah² Farah Latif Naz ${ }^{3}$
}

1. Ph. D Scholar, Department of Education, B.Z.U, Multan, Punjab, Pakistan

2. Professor (Retired) Department of Education, BZU Multan, Punjab, Pakistan

3. Lecturer, Department of Education, BZU Multan, Punjab, Pakistan

\begin{tabular}{|c|c|}
\hline PAPER INFO & BSTRACT \\
\hline $\begin{array}{l}\text { Received: } \\
\text { March 11, } 2021 \\
\text { Accepted: } \\
\text { May 30, } 2021 \\
\text { Online: } \\
\text { June } 05,2021 \\
\end{array}$ & $\begin{array}{l}\text { The main objective of this research was to find the correlation } \\
\text { among computer self-efficacy (C.S.E), perceived teaching skills } \\
\text { (P.T.S) and perceived research skills (P.R.S) of university } \\
\text { teachers regarding the use of ICT. The population was the } \\
\text { university teachers working in public sector universities of the }\end{array}$ \\
\hline $\begin{array}{l}\text { Keywords: } \\
\text { Computer Self - } \\
\text { Efficacy (C.S.E), } \\
\text { Correlation, } \\
\text { ICT in Teaching } \\
\text { and Research, } \\
\text { Self-Efficacy, } \\
\text { University } \\
\text { Teachers }\end{array}$ & $\begin{array}{l}\text { Punjab the province of Pakistan. The total number of } \\
\text { respondents (sample) in this research was nine hundred and } \\
\text { twenty three teachers. CSE was measured by the use of } \\
\text { Murphy's (1989) scale. P.T.S and P.R.S were calculated by } \\
\text { developing more items by the researcher. Cronbach's Alpha } \\
\text { coefficient of this tool was measured 0.98. The tool was } \\
\text { distributed personally. The data were analyzed by Arithmetic } \\
\text { means and coefficient of correlation. The results showed that } \\
\text { mean score depicted levels of C.S.E, P.T.S and P.R.S was at }\end{array}$ \\
\hline $\begin{array}{l}\text { *Corresponding } \\
\text { Author }\end{array}$ & $\begin{array}{l}\text { some confidence level. The results of the correlation analysis } \\
\text { depicted that there was a strong relationship between teachers' } \\
\text { CSE and PTS. The resulted value of correlation showed a strong } \\
\text { relationship between teachers' CSE and PRS. Considering these } \\
\text { results it was recommended that computer training for the use } \\
\text { in teaching and research must be compulsory to enhance the } \\
\text { CSE of teachers. }\end{array}$ \\
\hline
\end{tabular}

\section{Introduction}

During the recent years the computers are being used as teaching and learning tools. Therefore, the teachers and learners must receive computer training. In this scenario, the researchers of education conducted research to find teachers computer self-efficacy (CSE) in teaching and learning activities. These research studies revealed that high computer self-efficacy enhanced the computer competencies and further computer skills development of the teachers. The term self-efficacy was explained by Bandura (1997) that it refers to the belief in ability of any person to perform or complete a particular task. Campeau \& Higgins (1995) 
described the computer self-efficacy as the ability of any person to complete a task by using a computer. Research of Albion (2001) resulted that the computer selfefficacy of teaching faculty can predict their future use of computer ability in their teaching activities at class room level.

Recently, Salloum, et. al. (2019) revealed that computer self-efficacy had favorable impact on the use of e-learning mode of education for the technology users in the field of education. Research work of Ernawatiningsih \& Apriada, (2020) explored that positive attitude towards computer had significant affects towards use of latest technological equipment in academic activities in higher education institutions. Earlier researchers had also worked to explore the relation between CSE and its impact on teachers' integration of ICT in educational settings. For instance, Hong, et. al. (2014)revealed that computer self efficacy of teachers is directly proportional to the use of computer in class teaching and conducting research in Malasian educational institutions. In other words, as the computer self-efficacy increases the integration of technology in teaching and research also increases.

Similarly, Kazan \& EL-Daou, (2016) concluded that the students' academic progress whose teachers had higher levels of CSE was better than the students taught by teachers having lower levels of CSE. Moreover, EL-Daou, (2016) found that technology integration in teaching and research increased the teachers' competency in their professional development. Further , Efe,(2015 inferred that the teachers having higher levels of CSE proved more competency in application of ICT in teaching and research and used more internet for their instructional and research purposes.

In Pakistan the integration of ICT for educational activities was projected by National Academy of Higher Education (2002) during its second phase of incorporating technology in Education (ITE). In this project the faculty members were trained to use latest information and communication technology tools for educational and research activities. (Aziz, \& Akhtar, 2014). Realizing the significance of the recent requirements of use of ICT in education, the researcher decided to assess the relationship of computer self-efficacy of the University teachers in teaching and research.

\section{Literature Review}

\section{Computer Self-Efficacy}

Bandura (1977) stated that a person's sense of hope based on personal confidence on his abilities plays a role in the accomplishment of a particular assignment. Murphy (1989) defined the term Computer self-efficacy that it is the self judgment of any person to complete any function using a computer. 


\section{Role of Computer Self-Efficacy in Teaching and Research}

Computer technology is taking central place in the modern system of education. Langfords and Reeves (1998), revealed that computer self-efficacy is directly proportional to learning computer skills in teaching learning process. The significant role of C.S.E has been indicated by the research and study of Chua, Chen \&Wang (1999) which revealed that the positive attitude of a teacher towards use of computer accelerates the integration of advance technology for instructional purpose. The research study of Green (2000) suggested that for incorporate of ICT education the teaching of teachers for the use of hardware, software and networking of educational resource is necessary to update teaching profession. Zhao and Cziko (2001), resulted that computer self-efficacy increased the teachers' skills of incorporation of new technologies in instructional work.

Very few researchers worked to explore the impact of CSE on teachers' use of new technologies. For instance, Tweed, (2013), conducted a research study and its results suggested that computer self-efficacy possessed more importance as compared to the theoretical knowledge of teachers to use ICT. The research conducted by Litterell (2005), identified that computer self-efficacy is future indicator of trend of use of new technologies in classroom teaching. Kagima and Hausafus (2000), revealed that the successful users of technology in education possessed comparatively better levels of C.S.E as compared to reluctant users of new technology in teaching and learning process.

Research on integration of technology for educational purposes has been continued. Cormick and Ayers, (2009), concluded that self efficacy of faculty members to use technologies had higher relationship with their use in teaching and research activities. Teo (2009), concluded that computer self-efficacy was the major indicator of positive attitude to integrate technology for instructional and research work. Evers et. al, (2002) found that the faculty teachers possessing higher level of computer self-efficacy had more interest for learning innovative methods of teaching and research.

\section{Measurement of Computer Self-efficacy}

Keeping in the view the importance of C.S.E, Murphy (1989) developed standard scale for measurements of C.S.E. In this connection, Abbit \& Klett (2007) suggested that modifications in this scale were necessary due to updates in this computer technology. Furthermore, Lee \& Tsai (2010) added that along with the measurement of C.S.E it is also important to measure self-efficacy of use of internet. Realizing the use of technology, Alharbi \& Drew (2018, November) emphasized on the measurement of self efficacy and perceived use of technology in teaching and learning .Further they also developed technology acceptance model for discovering latest factors related to self efficacy and E-learning. Gultekin et. al. (2020) conducted a research study to investigate the self efficacy level of usage of internet of academic staff and revealed that the academic staff possessed sufficient level on internet 
integration in academic and research activities. The present study has been conducted by considering the importance of computer self-efficacy and its impact on teachers' skills to use the emerging modern technologies in teaching and research.

\section{Research Questions}

This research study was done to search the following key questions;

1. What are the levels of computer self-efficacy of teachers and their perceived use of ICT in teaching and research?

2. Is there any correlation between computer self-efficacy of teachers and perceived use of ICT in teaching?

3. Is there any correlation between computer self-efficacy of teachers and perceived use of ICT in research?

\section{Material and Methods}

\section{Research Design}

The present study used descriptive survey research design. Cohen, Manion \& Morrison (2000) suggested this design for collecting the data from large population.

\section{Population and Sample}

The teachers of the public sector universities in Punjab (Pakistan) were the entire population of the study. Over all five thousands nine hundred and twenty seven (5927) teachers were teaching in these universities. The sample of 1176 teachers was selected by randomly stratified technique. However, 923 teachers responded through the questionnaire out of 1176 teachers.

\section{Tool of the Study}

Computer Self-Efficacy Scale (from Murphy, Coover, \& Owen, 1989) was adopted as tool for the data collection for this research. However, for the assessment of use of ICT in teaching and research additional items were developed by the researcher. The detail of this questionnaire is described as under:

\section{Instrumentation}

The tool for this research study was consisted of two parts. The description of each part is given as follows:

First part contained the information asked about the demographics of the participants of the study; name, designation, gender, physical age, subject of teaching, number of teaching years, status of training about use of ICT, number of 
years of using ICT in teaching and research, status about ownership of computer and information about computer types.

In the second portion of the instrument there were questions to assess the computer self-efficacy as well as self beliefs to use ICT in teaching and research. There were fifty five questions in this questionnaire totally. Question one to ten were about general information about the respondents' demographics. Next twenty eight questions were about computer self-efficacy (CSE). Further seven questions were about perceived teaching skills (PTS). While the last ten questions were for the measurement of levels of the perceived research skills (PRS) of teachers for integration of information and communication technology (ICT).

Questions pertaining to assess the computer self-efficacy, perceived use of ICT in teaching and research had been formed according to Likert five point scale. The respondents were requested to answer all items. The subjects were ensured that all the information would be confidential. The statements of the questions were oriented to judge the computer self efficacy of teachers as well asits application for teaching and research activities.

\section{Content Validity of the Instruments}

The researcher sought the guidance of the senior and highly research experienced professors of the faculty of education and computer science at Bahauddin Zakariya University, Multan for the review of contents of the questions in the questionnaire of this research.

The questionnaire was reviewed by three professors related to this field for the purpose of establish content validity of all the items in this questionnaire. Therefore the items were improved in the light of the these experts.

\section{Reliability of the Instrument}

For the purpose of reliability of the items related to computer-self efficacy, perceived use of ICT in teaching and research Cronbach Alpha reliability coefficient was computed.

Table1

Calculated values of Reliability Coefficient.(Cronbach Alpha)

\begin{tabular}{ccc}
\hline Factors & No. of questions & Cronbach's Alpha \\
\hline CSE & 28 & 0.97 \\
\hline PTS & 07 & 0.92 \\
\hline PRS & 10 & 0.93 \\
\hline
\end{tabular}

Table 1 describes that the range of value of Cronbach's Alpha of individual items was observed from 0.88 to 0.97 . The calculated value of Cronbach's Alpha reliability coefficient of the entire instrument was 0.98 . 


\section{Pilot Study}

The researcher administered the questionnaire to the teachers of B.Z. University Multan for the pilot study. The feedback from these teachers was considered and some improvements in the statements of the items were made.

\section{Data Collection}

The researcher himself distributed the tool to the respondents and used postal services as per needs for time saving data gathering strategies.

\section{Data Analysis}

The researcher used software named Statistic 8.1 and SPSS for data analysis for this study. This analysis was conducted by calculation of mean and standard deviation for first research question. While for second and third research questions, Pearson correlation coefficients were computed accordingly as given in the following tables.

\section{Results and Discussion}

\section{First Research Question}

What are the levels of computer self-efficacy of teachers and their perceived use of ICT in teaching and research?

Table 2

Mean scores of the participant's levels of computer self-efficacy, perceived use of ICT in teaching and perceived use of ICT in research.

\begin{tabular}{cccc}
\hline & MEAN SCORE & S.D & N \\
\hline CSE & 3.42 & .21 & 923 \\
\hline PTS & 2.99 & .02 & 923 \\
\hline PRS & 2.97 & .01 & 923 \\
\hline
\end{tabular}

Table. 2 shows that the mean score of teachers' computer self efficacy was 3.42.Thisvalue suggested that the level of computer self efficacy of the majority of the teachers was at some confidence level.

From table.2, it is clear that mean score of the teachers' perceived use of ICT in teaching was 2.99; that was nearly equal to 3.00. This value suggested that teachers' perceived use of ICT in teaching was also at some confidence level.

Table 2 depicts that mean score of the teachers' perceived use of ICT in research was 2.97; that was nearly equal to 3.00. This value suggested that teachers' perceived use of ICT in research was also at some confidence level. 


\section{Second Research Question}

Is there any correlation between computer self-efficacy of teachers and perceived use of ICT in teaching?

Table 3

Correlation between teachers' computer self-efficacy and perceived use of ICT in teaching

\begin{tabular}{ccc}
\multicolumn{3}{c}{ teaching } \\
\hline \multirow{2}{*}{ CSE } & 0.798 & Pearson correlation \\
& & Sig(2.Tailed) \\
N=923
\end{tabular}

Table 3 shows that the Pearson correlation coefficient value was 0.798 . This value revealed that there was a high and positive correlation between teachers' computer self-efficacy and their perceived use of ICT in teaching. It resulted that there was strong relationship between teachers' computer self-efficacy and perceived use of ICT in teaching activities.

\section{Third Research Question}

Is there any correlation between computer self-efficacy of teachers and perceived use of ICT in research?

Table 4

Correlation between computer self-efficacy of teachers and perceived use of ICT in research PRS

CSE 0.782

Pearson correlation $\operatorname{Sig}(2$. Tailed) $\mathrm{N}=923$

Table 4 shows that the Pearson correlation coefficient value was 0.782 . This value revealed that there was a high and positive correlation between teachers' computer self-efficacy and their perceived use of ICT in research. It resulted that there was strong relationship between teachers' computer self-efficacy and their self beliefs for incorporation of ICT for instructional and research activities.

\section{Conclusions}

1. The calculated values of mean scores of the teachers' computer self-efficacy, their perceived use of ICT in teaching and research revealed that teachers believed themselves at some confidence level. This level needs to be improved.

2. The calculated values of correlation coefficient showed a high and positive relation between teachers' computer self-efficacy and their perceived use of ICT 
in teaching. Therefore, it is concluded that teachers' computer self efficacy and use in ICT in teaching activities have strong relationship.

3. The calculated values of correlation coefficient showed a high and positive relation between teachers' computer self-efficacy and their perceived use of ICT in research. Therefore, it is concluded that teachers' computer self-efficacy and use in ICT in research activities have strong relationship.

\section{Discussion}

This research study resulted that the teachers were at some confidence levels of computer self efficacy (C.S.E), perceived teaching skills (P.T.S), and perceived research skills (P.R.S) regarding the use of ICT. These results corroborated with the results of Embi's study.(2007), he revealed that the most of the university teachers showed higher computer self-efficacy in Malaysia. The present research reported the strong correlation among teachers' computer self-efficacy, their self belief about the usage of ICT in teaching and research activities. The present results matched with conclusion of Ertmer and Ottenbreit Leftwich, (2010), which revealed that computer self-efficacy possessed more importance as compared to the theoretical knowledge of teachers to use ICT. This research also confirmed the results of Mc Cormick and Ayers, (2009), who concluded that self efficacy of faculty members to use technologies had higher relationship with their use in teaching and research activities. The present results confirmed the findings of Evers et al.(2002), which concluded that the teachers who had higher self-efficacy, were more curious about learning new technologies of education. The findings of this study matched with the findings of Harrison and Rainer (1997) that the higher levels of computer selfefficacy caused to enhance the learning of computer skills in teachers. The present results also confirmed the research findings of Chua, Chenand Wang (1999), who identified that higher level of computer self efficacy indicated higher quality of computer use in teaching and research by the faculty members. The present research supported the findings of Compeau and Higgins (1995), as they resulted that the people who had greater computer self efficacy, they had more belief to apply new technologies. These results were matched with the findings of Albion (2001), that revealed that computer self-efficacy of teaching staff was the main indicator of integration of computer technology in instructional work. The present results also agreed with the findings of Hirschbuhl and Bayesian (1994), who concluded that computer self efficacy was the important factor for incorporation of technology in educational as well as research work. Over all, the conclusions of the present research supported the results of research of Faseyitan (1996), which revealed that the teaching faculty members with higher computer-self efficacy succeeded to integrate technology in educational activities with more confidence.

\section{Recommendations}

1. On the basis of above conclusions and discussion the researcher recommends that to enhance the confidence level of ICT integration training should be 
compulsory for all faculty members. As it is concluded that teaching faculty member's computer self efficacy and perceived use in ICT in teaching process have strong relationship. Therefore the computer usage workshops and seminars should be planned to enhance the CSE of the university teachers before the commencement of new academic sessions every year.

2. The above conclusions revealed that the faculty members' computer self efficacy and perceived use in ICT in research activities have strong relationship. Hence, the special refresher courses should be arranged to increase the CSE of university faculty regarding the use of internet, software and computer applications in academic research requirements.

3. More studies should be conducted by including the latest technological applications and software for integration in teaching and research activities. The present research can be extended by adding the comparison of more variables such as economic status, foreign university qualified, local university qualified and permanent faculty or visiting status of the university teachers. 


\section{References}

Abbitt, J. T., \& Klett, M. D. (2007). Identifying influences on attitudes and selfefficacy beliefs towards technology integration among pre-service educators. Electronic Journal for the integration of technology in Education, 6(1), 28-42.

Albion, P. R. (2001). Some factors in the development of self-efficacy beliefs for computer use among teacher education students. Journal of Technology and Teacher Education, 9(3), 321-347.

Alharbi, S., \& Drew, S. (2018, November). The Role of Self-efficacy in Technology Acceptance. In Proceedings of the Future Technologies Conference (pp. 1142-1150). Springer, Cham.

Aziz, F., \& Akhtar, M. M. S. (2014). Impact of training on teachers competencies at higher education level in Pakistan. Researchers World, 5(1), 121.

Bandura, A. (1977). Self-efficacy: Toward a unifying theory of behavioral change. Psychological Review, 84, 191-215.

Bandura, A. (1997). Self-efficacy: The exercise of control. New York, NY: W.H. Freeman.

Chua, S. L., Chen, D., \& Wong, A. F. L. (1999). Computer anxiety and its correlates: A meta-analysis. Computers in Human Behavior, 15, 609-623.

Cohen, L., Manion, L., \& Morrison, K. (2017). Research methods in education. Routledge.

Compeau, D., \& Higgins, C. (1995). Computer self-efficacy: Development of a measure and initial test. MIS Quarterly,19, 189-211.

Efe, H. A. (2015). The relation between science student teachers' educational use ofweb 2.0 technologies and their computer self-efficacy. Journal of Baltic Science Education, 14(1), 142.

EL-Daou, B. M. N. (2016). The Effect of Using Computer Skills on Teachers' Perceived Self-Efficacy Beliefs towards Technology Integration, Attitudes and Performance. World Journal on Educational Technology: Current Issues, 8(2), 106-118

Embi,R.(2007). Computer Anxiety and Computer Self-Efficacy among Accounting Educators at University Teknologi Mara (UITM), MALAYSIA.Ph.D.Dissertation, Faculty of the Virginia Polytechnic Institute and State University. Blacksburg, Virginia.

Ernawatiningsih, N. P. L., \& Apriada, K. (2020). The Effects of the Tri Hita Karana Culture, Computer Anxiety, Computer Attitude, and Computer Self Efficacy on the Interest of Accounting Students of Private Universities in Denpasar City to 
Use Accounting Software. International Journal of Accounting $\mathcal{E}$ Finance in Asia Pasific (IJAFAP), 3(1), 27-31

Ertmer, P. A., \& Ottenbreit-Leftwich, A. T. (2010). Teacher technology change: How knowledge, confidence, beliefs, and culture intersect. Journal of research on Technology in Education, 42(3), 255-284.

Evers, W., Brouwers, A., \& Tomic, W. (2002). Burnout and self-efficacy: A study on teachers' beliefs when implementing an innovative educational system in the Netherlands. British Journal of Educational Psychology, 72, 227-243.

Faseyitan, S., Libii, J. N., \& Hirschbuhl, J. (1996). An in service model for enhancing faculty computer selfefficacy. British Journal of Educational Technology, 27, 214-226.

Green, K. C. (2000). The Real IT Challenge: People, Not Products. Converge.

Gültekin, O., Erkaplan, S., Uzun, H., \& Güney, E. (2020). Investigation of Academic Staff's Self-Efficacy Using the Educational Internet. Higher Education Studies, 10(3), 26-33.

Harrison. A. \& Rainer.K (1997).The influence of individual differences on skill in end user computing. Journal of Management Information Systems, 9, 93-111.

Hong, K. S., Chai, M. L., Tan, K. W., Hasbee, U., \& Ting, L. N. (2014). ESL Teachers' Computer Self-Efficacy, Attitudes Toward Computer and Classroom Computer Use. Pertanika Journal of Social Sciences \& Humanities, 22(2).

Kagima, L. K., \& Hausafus, C. O. (2000). Integration of electronic communication in higher education: Contributions of faculty computer self-efficacy. The Internet and Higher Education, 2(4), 221-235.

Kazan, S., \& EL-Daou, B. (2016). The Relationship between Teachers' Self-Efficacy, Attitudes towards ICT Usefulness and Students' Science Performance in the Lebanese Inclusive Schools 2015. World Journal on Educational Technology: Current Issues, 8(3), 277-293.

Langford, M. and Reeves, T.E (1998).The relationship between computer self-efficacy and personal characteristics of the beginning information systems student. Journal of Computer Information Systems, 38(4), 41-45

Lee, M.H. \& Tsai, C.C. (2010). Exploring Teachers' Perceived Self Efficacy and Technological Pedagogical Content Knowledge with Respect to Educational Use of the World Wide Web. Instructional Science: An International Journal of the Learning Sciences, 38(1), 1-21. 
Litterell, A.B., Zagumny, M.J. \& Zagumny, L.L. (2005). Contextual and psychological predictors of instructional technology use in rural classrooms, Educational Research Quarterly, vol. 29, no. 2, 37-47.

McCormick, J., \& Ayers, P. (2009). Teacher self-efficacy and occupational stress: A major Australian curriculum reform revisited. Journal of Educational Administration, 47(4), 463-476.

Murphy, C. A., Coover, D., \& Owen, S. V. (1989). Development and validation of the Computer Self-Efficacy Scale. Educational and Psychological Measurement, 49, 893899.

Salloum, S. A., Alhamad, A. Q. M., Al-Emran, M., Monem, A. A., \& Shaalan, K. (2019). Exploring students' acceptance of e-learning through the development of a comprehensive technology acceptance model. IEEE Access, 7, 128445-128462.

Soomro, K. A. (2015). Digital divide among Pakistani faculty regarding their information and communication technology (ICT) access. Graduate Theses, $\begin{array}{llll}\text { Dissertations, } & \text { and } & \text { Problem }\end{array}$ https:/ / researchrepository.wvu.edu/etd/6692

Teo, T. (2009). Modeling technology acceptance in education: A study of pre-service teachers. Computers $\mathcal{E}$ Education, 52(1), 302-312.

Tweed,S.R.(2013).Technology Implementation: Teacher Age, Experience, Self-Efficacy, and Professional Development as Related to Classroom Technology Integration. East Tennessee State University. Electronic Thesis and Dissertations. Paper 1109.http:/ / dc.etsu.edu/etd/1109

Zhao, Y. \& Cziko, G. A. (2001). Teacher adoption of technology: A perceptual control theory perspective. Journal of Technology and Teacher Education, 9(1), 5-30. 